In light microscopy findings, calcification of the chondral matrix and ossification were active. In scanning electron microscopy findings, dense calcospherites, distinct chondral lacunae, regularly running collagen fibers, and border lines were noted. In transmission electron microscopy findings, we found that the osteoblasts were active, the ruffled border of osteoclast was decrease, indicated this osteoclast is inactive.

In conclusion, dietary therapy using combined ipriflavone and $1 \alpha-\mathrm{OH}-\mathrm{D}_{3}$ promoted recovery in debilitated metaphysis tibia.

\title{
4.レーザー光を利用した歯肉縁下歯石検出の試み
}

栗原えりこ（九歯大·予 歯）

歯肉縁下歯石の確実な検出を目的とし,レーザー蛍光法を用いて客観的な検出の可能性を検討した. 歯肉縁下歯石, 根面僃蝕, 口腔内硬組織, 細菌, 血液を測定材料とし, それぞれのサンプルの励起スペクトルおよび蛍光スペクトル を得て検討を重ねた。また歯周疾患モデルの自己蛍光像を CCD カメラにて記録した。㐘肉縁下歯石扔よび根面轗蝕 は波長 $635 \mathrm{~nm}$ および $655 \mathrm{~nm}$ で励起すると健全硬組織にはない特徴的な蛍光スペクトルが認められた。 また，歯周 疾患モデルに $633 \mathrm{~nm}$ のレーザー光を照射し, $700 \mathrm{~nm}$ の光学フィルターを介して得られた自己虽光像は歯肉縁下歯 石の検出が可能であった，よって，レーザー蛍光法は病的根面状態の検出が可能であることが示された。

\section{Detection of Subgingival calculus and dentine caries by laser fluorescence}

Eriko Kurihara (Department of Preventive Dentistry, Kyushu Dental College)

We examined the possibility of subgingival calculus detection using autofluorescence induced by laser irritation. Autofluorescence was measured at various excitation and emission wavelength settings in 5 specimens each of sound dentine and enamel, subgingival calculus, and root caries. Periodontopathic model teeth were also photographed as autofluorescence images. Subgingival calculus and dentine caries showed a characteristic emission, however, sound dentine or enamel did not. The autofluorescent images photographed at an excitation of $633 \mathrm{~nm}$ provided clear calculus identification in periodontopathic model teeth when a $700 \mathrm{~nm}$ optic filter was used. Thus, the autofluorescence method was found to be a powerful tool for detecting subgingival calculus and root caries.

\section{5. 上顎前歯の前後的位置と口唇閉鎖機能における口唇の筋活動との関係}

今村 富貴（九歯大·歯矯正）

本研究では上顎切歯唇面に置いた dummyによって overjet を変化させた時の口唇の閉鎖機能を検討した。唇閉 鎖々離開時の下唇の活動電位の差をもとに被験者を分類した山口らの方法を修正し,筋活動の変化率より被験者を incompetent lip 群 (11名), competent lip 群 (10 名)に分類した.

下唇において両群ともに overjet の増加と口唇閉鎖時の筋活動には有意な正の相関関係が認められ，その回帰直線 の傾斜は, incompetent lip 群が competent lip 群より有意に大きかった. 筋活動の变化率との間の回帰直線の勾配 は competent lip 群の方が incompetent lip 群より急勾配であった. competent lip 群において lip incompetent （無力性口唇）が認められたのは overjetが $6 \mathrm{~mm}$ 以上になってからであった.

以上により上顎切歯の位置の変化による overjetの増加において incompetent lip 群ばかりではなく, competent lip 群においても lip incompetent（無力性口唇）の影響を及ぼしていることが示唆された.

\section{Activity of lip muscles associated with simulated upper incisors position}

Fuki Imamura (Department of Preventive Dentistry, Kyushu Dental College)

The lip function associated with lip sealing was studied by recording the electromyographic (EMG) activity of the lips, while dummies were placed on the upper incisors to increase overjet. Subjects were 
divided into 10 competent lip group and 11 incompetent lip group based on the EMG activity of the lower lip.

EMG activities of lips were significantly correlated with increased overjet in the competent lip and incompetent lip groups, respectively.

It is suggested that increased overjet by labial tipping of the upper incisors is affecting the lip incompetence in the competent lip subjects, but not in the incompetent lip subjects.

\section{Class III不正咬合者の咀嚼運動 一正常咬合者と不正咬合者の咀嚼運動の比較一}

田村 仁美（九歯大·歯矯正） 骨格性下顎前突者の咀嚼運動の研究は少なく，その特徴は明らかではない，本研究では冎格性下䫟前突者の咀嚼時 の顎運動と咀㘉筋活動を調查した．被験者は正常咬合を有する 20 名の Normal 群之骨格性下顎前突で第一大臼歯の 咬合関係が Class III かつ cross bite を伴う 20 名の Class III群とした，咀嚼時の切歯点経路と咬筋，側頭筋前部にお ける筋電図を同時記録し, 開口位, 咀嚼終末位の座標値と筋電図波形タイミングについて 2 群の比較を行った. 結果, Class III 群は Normal 群よりも開口位が後方, 作業側に存在しており, 咀嚼終末位は平衡側に存在していた。また, Class III 群は Normal 群よりも咀嚼周期に対する閉口相時間の割合が大きく, 筋活動収束時間, 活動時間の延長が認 められた. 以上より, 骨格性下顎前突者の咀嚼運動の特徵が明らかとなり, 治療後の咀嚼機能の評価の一助となると 考えられる。

\section{Masticatory Movement of Skeletol Class III Malocclusion}

Hitomi Tamura (Department of Orthodontics, Kyushu Dental College)

The mandibular movements and the EMG activity of the masseter and temporalis muscles were simultaneously recorded by Gnathohexagraph during chewing a gum in 40 adult subjects. They consisted of 20 Class I and 20 Class III subjects. The timings for the onset, peak, and offset of EMG activity during chewing a gum were estimated relative to the maximum opening and occlusal terminal points in the traces of incisor point. The following results were obtained; (1) The maximum mouth opening position shifted to the working side in Class III subjects as compared with Class I subjects. (2) The occlusal terminal position shifted to the balancing side in Class III subjects. (3) The ratio of closing phase to a chewing cycle was significantly greater in Class III subjects than in Class I subjects. (4) Duration of EMG activity was longer in Class III subjects than in Class I subjects due to the extended offset time of EMG activity.

These results suggest that the size and position of the mandible and the inter-occlusal relationship could influence the masticatory movement.

\section{2 月例会講演抄録}

\section{1. 成長期ラット下顎骨におけるブドウ種子エキスの影響}

神谷 祐行 (九歯大·小児歯)

本研究はフブドウ種子エキスの下顎骨に及ぼす影響を力学的解析により明らかにした．５週齢のWistar 系雄ラッ トを, (1)対照群(2)低カルシゥム食群（30％カルシゥム) (3)低カルシゥム食・標準食群(4)低カルシゥム食·GSPE 配合標 準食群に分けて 6 週間飼育した。飼育終了後, 下顎骨を $\mathrm{pQCT}$ による三次元的手法を用いて, 海綿骨と皮質骨に区別 し, 骨塩量, 骨密度, 断面積, 骨強度指標の形態計測学的解析を行った。海綿骨骨塩量, 海綿骨骨密度, 皮質骨骨塩 量, 皮質骨骨密度, 骨強度指標（X軸，Y軸）に関しては $5 \%$ の危険率，皮質骨断面積は $1 \%$ の危険率で(4)群は(3)群 より有意に高値を示した，以上のことから，GSPEはラット虚弱下顎骨に対して骨質並びに骨強度を増大させ，骨の 内部構造を促進させることが明らかとなった。 